\title{
Is Microfinance Service a Positive Sum Game? A Qualitative Study on Financial Sustainability of Microfinance Clients
}

\author{
M sai Mohini* \\ Department of management studies, National institute of technology ,Trichy -15 \\ Dr V Lavanya \\ Department of management studies, National institute of technology ,Trichy - 15
}

\begin{abstract}
To explore the impact of microfinance on the financial sustainability of clients. The author set out to determine to what extent do the clients utilize the funds to gain and reinvest in the business to accomplish sustainability.The study is based on an in-depth interview which was conducted with microfinance clients. A qualitative approach was used to capture the data. In-depth interviews were conducted using Thematic analysis method and secondary data from microfinance office records to capture their practices in operational utilization of funds. The finding of the study shows that the loan amount was not fully utilized for specified purposes and was used to meet the basic needs and contingencies. The respondents were influenced and unbalanced during the utilization of funds. Most of them treat their debt as an additional source of fund to meet their family responsibility.
\end{abstract}

Keywords: Financial sustainability of clients, operational evaluation, qualitative method, thematic analysis, Biases, Microfinance, India

DOI: $10.7176 / \mathrm{EJBM} / 11-10-05$

Publication date: April $30^{\text {th }} 2019$

\section{Introduction}

The poor are poor not because they are untrained or illiterate because they cannot retain the return of their labor. They have to control over their livelihood, and it is the ability to sustain their existence that gives the people the power to rise out of poverty.

-Muhammad Yunus

Microfinance industry is rising rapidly nowadays. It is most vital to maintaining financial sustainability to fulfill their mission of economic growth and to develop their services to customers. It is ensuring not only economic feasibility but also their profitability. Financial exclusion must persist the top priority for the reason that microfinance remains one of the tools to achieve economic progress. The impact of this depends on how it is operated and monitored. Proper implementation can have a real positive impact on poor people who stay at the base of the pyramid. According to microfinance global report 2017, the number of MFI clients has reached more than 139 million low income and unserved poor worldwide. Absolutely this huge number plus expected growth in participation leads to the financial sustainability of MFIs but does it result in enhancing the financial sustainability of clients? Thapa G (2007)explained that the sustainability of microfinance institute can be financial and operational. Financial sustainability is the most prominent one. A microfinance institute (MFI) is thought to be sustainable when it will cover all its operational expenses from income earned through financial services provided after adjusting for inflation and subsidies. (Natilson and Bruett,2001; Rosenberg, 2009; Dzene and Aseidu 2010).Similarly, financial sustainability of the client means the ability to survive without the assistance of a lender after a certain initial period, achieve steady cash flow from their venture (Saju Jose and Jacob Chacko 2017).

Microfinance has facilitated the poor to access basic services which are not normally accessible to them due to the poverty, illiteracy or location disadvantage. Microfinance appears to offer a "win-win" solution, where both financial institutions and poor clients profit (Morduch, 1999). Undeniably, some of the innovations and revolutions have brought significance effect on the poor. One of the recent revolutions in microfinance is the change of focus from social mission to profit motive which is emerged as "mission drift" (Aubert et al, 2009; Copestake 2007; Mersland and stroma, 2010 Xu et al 2016; Serrano-cinca et al 2016). A microfinance institute needs to have a goal to deliver tangible socio-economic benefit which will improve the livelihood of the customers(Acharya and Acharya 2006 ). This means that the bottom of the pyramid customers should be able to get a steady surplus from their venture without assistance after its liabilities have been paid off. However, some critic dreads that microfinance institute has too focused on making profits at the costs of outreach and sustainability of the poor customers (Ambe Shu and Oney, 2014).

Many studies have been conducted on the impact of microfinance on the welfare of the clients, but not much is explored about its impact on the financial sustainability of the clients. The objective of the study is to gain insight into the financial sustainability of the client.

RQ: Do microfinance program positively improves the financial sustainability of MFI clients? In other words, 
how well, this contributes towards financial upliftment of sustainable growth. The study tries to evaluate the impact through a qualitative assessment using thematic analysis method.

The rest of the paper is divided into seven sections. Section two deals with brief about MFIs in India. Section three gives an overview of literature reviews, followed by section four and five Methods and data analysis. Section six describes findings and section seven highlights the conclusion, limitation, and future research.

\section{MFIs in India}

Microfinance institutions provide loans, savings, and other basic financial services to the poor in an effort to help in alleviating poverty (CGAP 2011; Morduch 1999). The microfinance literature has enlightened the benefits of microfinance to economic and social developments by both MFIs lenders and borrowers (Goldberg 2005; Odell 2010)The borrowers can use the loans provided by MFIs and become entrepreneurs by creating and growing by microenterprise that are characterized by small employment generation with a small net worth with informal operations (Gudz,1999). The motto behind this is to enhance the financial sustainability and to progress in the standard of living to exterminate poverty. These MFIs aims at providing microcredits without having any collaterals or securities to clients for investing in small ventures which will, in turn, give them returns for achieving sustainability.

Morduch (2000) argues that only MFIs that pursue best practices or "principle of good banking " can alleviate poverty and attain sustainability. It established a significant start in 1976 when a Bangladesh professor, Muhammed Yunus, used his own money to make \$27 loan to 42 village women .Microfinance in India is growing rapidly. It is provided by almost all the new generation banks, multinational companies, and NGOs. Some of the new age banks in India pursue microfinance strategies as part of their CSR (Brugmann J; Prahalad, 2007). India has a large number of people who are poor and who consequently unbanked. The Indian economy is growing. The gross domestic product is now growing at a rate more than $6.74 \%$ (RBI 2017). A majority of people in India persist outside the reach of the formal financial system. The significance of microfinance services is a vital and effective tool in the battle against poverty and to attain sustainability.

Today, poverty continues to be experienced by a significant portion of the population living in remote and low-density regions. In order to contribute towards poverty alleviation, MFI has emerged. However, microfinance offered by NGOs, NBFC companies, cooperatives (including village financial service cooperative ) and NBFC-MFIs in various different models. Group lending model is considered as the better and safer option among different models of lending(Shirsendu Mukherjee Sukkanta Bhattacharya 2015). The main aim is to provide opportunities to foster small entrepreneurial activities that can contribute to social and economic growth and aid in the alleviation of poverty ( Barr,2005; Beck et al 2007; Kendall et al 2010 ) .poverty must be seen as the deficiency of basic capabilities rather than merely a low income. World bank report on international poverty line that the world has made tremendous progress in reducing extreme poverty. The percentage of people living in extreme poverty globally fell to a new low of 10 percent in 2015 from 11 percent in 2013 and reflecting at slower progress. Despite this optimistic portrait of the path towards the target, there are reasons for concern. One reason that the existence of some evidence that the rate of poverty reduction has lowered down. To assess this recent change in the path of poverty reduction indicates a warning signal. In southern Asia region, four out of five extreme poor reside in India despite the poverty rate of 13.4 percent. India 's large population of 1.3 billion results in a high absolute number of poor. To achieve the global poverty goal, progress in poverty reduction needs to continue at a high rate in India. Mission drift (Mia MA; Lee H A) shows that the MFI has deviated from the original intent of serving the poorest of poor, misshapen in the way that violets the business ethics. Moreover, the father of microfinance Muhammad Yunus has expressed his unhappiness and fear about the future of MFI due to the surge of Profit-making MFIs. Does the goal of sustainability and profitability motive of the company have a negative influence on the sustainability of MFI clients need to be discovered?

\section{Broader literature on MFI and sustainability}

A number of studies have shown a substantial impact on the lives of people benefiting from microfinance across the globe. A wide range of economic and social upliftment, including better access to education for children, health nutrition and greater empowerment of women. (Britta Augsburg et al,2015; Bruno Crepon et al, 2015; Mazumder (2015). All these recent studies found the access to the microcredit has a positive impact on investment of self-employed activities but no significant impact on overall growth.

Several kinds of literature presented that women are more responsibility-oriented people who meet the basic needs of families as well as the struggle for the livelihood of the family. They take up the business with the primary aim of meeting these needs. The growth of business remains secondary (Brunjes and Diez, 2013). Most of the clients hold micro businesses with limited resources. Various empirical studies being conducted to study the financial sustainability of Microfinance institutions using financial performance measurements. Very Scarce literature on Impact assessment of MFI clients on their financial sustainability. RQ: Do the MFI clients are actually able to get sustainability after using microfinance services? In other words, an answer to our research 
can be explored by following questions. RQ: How do the MFI clients use their loans? Is it effectively utilized for business purpose? Do they reinvest the returns for further growth and sustainability?

The magnitude of MFI impact on the client's financial sustainability via their cost and benefit analysis will deliver a solid guideline to the decision maker, policy maker, management and donor etc about initiation of innovative products to meet the real needs of clients. our research aims at a qualitative analysis to gauge the potential impact that the microfinance program may generate through in-depth and group-based interviews.

Impact evaluation framework of MFI fig 1

\begin{tabular}{|c|c|c|c|c|}
\hline Allocation & Input & Output & Outcome & Impact \\
\hline - MFI mission & $\begin{array}{l}\text { - Financial } \\
\text { services } \\
\text { - Non financial } \\
\text { services } \\
\text { - Training to } \\
\text { clients }\end{array}$ & $\begin{array}{l}\text { - Access to loan } \\
\text { - Affordability of } \\
\text { tariff } \\
\text { - Doorstep } \\
\text { services }\end{array}$ & $\begin{array}{l}\text { - Reduction in } \\
\text { coping cost } \\
\text { - Increasing } \\
\text { productivity } \\
\text { - Improving } \\
\text { children } \\
\text { education } \\
\text { - Improve in } \\
\text { health } \\
\text { conditions } \\
\text { - Reduced } \\
\text { indoor } \\
\text { pollution }\end{array}$ & $\begin{array}{l}\text { - Income } \\
\text { - Education } \\
\text { - Health } \\
\text { - Environment } \\
\text { - Women } \\
\text { empowerment }\end{array}$ \\
\hline
\end{tabular}

Source: a handbook on impact assessment : A qualitative method

\section{Methods}

Researcher's objective to understand the financial sustainability of MFI clients. Various studies have given shreds of evidence that MFIs gives positive impact in their lives of poor as output and impact aspects are shown in the above framework (shown in fig 1 ) but fewer number of studies were conducted to find its impact on financial sustainability. The researcher has attempted to identify the gap in attaining financial sustainability by the clients through a qualitative method. In order to support research, aim this study undertaken using a qualitative approach to scale potential impacts that the program may generate through using in-depth and groupbased interviews. In other words, a qualitative inquiry that investigates a contemporary phenomenon within its real-life context is in order to allow an in-depth understanding of how MFI programs impact on the enhancement of financial sustainability of clients. In this research, the thematic analysis method was used along with three sources of evidence that are documentation, interviews, and records from MFIs . The researcher approached the management officials cluster heads, divisional managers of respective MFIs to conduct the study. A women group leaders were introduced along with the group members of that region at Kandhamal, Odisha state, India . Then reviewed publicly available information relating to the MFIs under study and some of their private records. In the second stage, the researcher visited the selected institutions which involved detailed discussions with loan officers. Then the arrangements were made by officials to meet the clients in the center meetings. Individual and group interviews were done at each visit in the field. MFIs and client information's were kept completely confidential. All the contributing MFIs were registered under NBFC-MFI and are incorporated under the companies act 1956 and registered as a non-bank financial company with RBI, like other companies incorporated under the company act. These NBFC work purely business lines laying emphasis on return on investment by "doing good business while extending microfinance to the poor" that is "doing well by doing good" is their motive.

Thematic analysis method was used to analyze the qualitative data which facilitated identification, analysis and reporting patterns as given by Braun and Clark's six phases in which codes were developed after examining the data. An advantage of this, particularly from the perspective of learning that it is a method rather than a methodology (Braun and Clark 2006,2013) It means that unlike many quantitative methodologies it is not tied with a particular epistemological or theoretical perspective. The goal of the thematic analysis is to identify the themes i.e. pattern in data that are important.

In the first stage, the researcher began by familiarizing with the data, reading the whole data multiple times to establish meaning. Then note down the ideas about what is there in the data and the important focal points in that. In the second stage after generating the initial list, initial codes were assigned. Coding was done manually by writing notes and by using highlighters to indicate the potential patterns and identified codes were matched up 
with data extracted from the individual transcript. In the third stage began when all data have been initial coded and collated, this entitles sorting the different codes into potential themes. The coded data were grouped into themes. The fourth stage involves the refinement of the theme. At stage five, the initial themes were defined identifying the essence of what each theme is about and determine which aspect of the data each theme captured. The sixth stage involves writing up the story, providing sufficient evidence of the themes within the data. (Braun and Clark 2006,2013)

\section{Data and analysis:}

Demographic features of respondents:

Table -1

\begin{tabular}{|l|l|}
\hline Nature of business & $\begin{array}{l}\text { petty shops, tailoring, vegetable vendors, agricultural products, foodstuff retailing, } \\
\text { idly batter shops, a small unit of use and throw plates manufacturing unit, poultry } \\
\text { farms, milk dairy, stationery shop, tiffin centers etc }\end{array}$ \\
\hline Age group & 25-35years - 6 respondents \\
& $36-45$ years -4 respondents \\
& $46-55$ years -7 respondents \\
& $55-60$ years -3 respondents \\
\hline Education & Primary, secondary -12 respondents \\
& Vocational, diploma courses- 8 respondents \\
\hline Number of children & $1-3-14$ respondents \\
& $4-5$ and more -6 respondents \\
\hline Monthly income (Rs) & $5000-10000-8$ respondents \\
& $10000-15000-5$ respondents \\
& $15000-20000-5$ respondents \\
Investment in the & Ranges from 20000 to 100000 \\
business (Rs) & \\
\hline
\end{tabular}

Three villages were selected based on the poverty status as reported by the cluster heads survey for investigating the impact on client's financial sustainability. Data were collected by the researcher during the field visit accompanied by cluster head and field officer after the center meeting for around 1 hour to 1 hour 30 minutes duration using face to face interviews. All sessions were conducted in local language odia. Questions were asked by the researcher for the individual in-depth interviews and data were generated, audiotaped and translated into English. At the beginning of the center, meeting oath was taken by both the loan officers and the client. After a week of training, the loan amount usually get disbursed to the clients. The sample size was 20 who engaged in various businesses like petty shops, tailoring, vegetable vendors, agricultural products, foodstuff retailing, idly batter shops, the small unit of use and throw plates manufacturing unit, poultry farms, milk dairy, tiffin centers etc. They were clustered into three focus groups with six, seven and seven in three groups and data were generated regarding operational utilization of funds shown in table 2.

Table -2

\begin{tabular}{|c|c|c|c|c|}
\hline Respondents & Example from the raw data & $\begin{array}{l}\text { Theme 1- } \\
\text { impact }\end{array}$ & $\begin{array}{ll}\text { Theme } & 2- \\
\text { utilization } & \text { of } \\
\text { funds } & \\
\end{array}$ & $\begin{array}{l}\text { Theme }-3 \\
\text { funds utilized } \\
\text { /diverted }\end{array}$ \\
\hline 1 & $\begin{array}{l}\text { I have } 3 \text { girls. I have a petty shop started } \\
\text { with a small investment of } 10000 \text {. I got a } \\
\text { loan of Rs } 30000 \text {. Now invested in my } \\
\text { business. Its running good, me and my } \\
\text { husband together take care of the shop. Two } \\
\text { daughters are going to college for higher } \\
\text { education and third in 10th std. It helped us } \\
\text { to improve our monthly income. }\end{array}$ & $\begin{array}{l}\text { Improved } \\
\text { standard of } \\
\text { living and } \\
\text { their kids' } \\
\text { education }\end{array}$ & $\begin{array}{lr}\begin{array}{l}\text { Priority } \\
\text { given }\end{array} & \text { is } \\
\text { standard } & \text { to } \\
\text { living } & \text { and } \\
\text { education } & \end{array}$ & $\begin{array}{l}\text { Funds utilized } \\
\text { fully }\end{array}$ \\
\hline
\end{tabular}




\begin{tabular}{|c|c|c|c|c|}
\hline Respondents & Example from the raw data & $\begin{array}{l}\text { Theme 1- } \\
\text { impact }\end{array}$ & $\begin{array}{ll}\text { Theme } & 2- \\
\text { utilization } & \text { of } \\
\text { funds } & \\
\end{array}$ & $\begin{array}{l}\text { Theme }-3 \\
\text { funds utilized } \\
\text { /diverted }\end{array}$ \\
\hline 2 & $\begin{array}{l}\text { I am a widow. I have one son and one } \\
\text { daughter. Two years back husband passed } \\
\text { out. I have three machinery unit for } \\
\text { manufacturing use and throw paper and } \\
\text { wooden plates and cups. I had taken a loan } \\
\text { of } 45000 \text { to buy these three machines. My } \\
\text { son also helping me to sell it to retail shops. } \\
\text { Income generated from this I am saving for } \\
\text { my daughter's marriage. }\end{array}$ & $\begin{array}{l}\text { Income } \\
\text { generated for } \\
\text { children's } \\
\text { future }\end{array}$ & $\begin{array}{l}\text { Planning to } \\
\text { give a good } \\
\text { life to children }\end{array}$ & $\begin{array}{l}\text { Funds utilized } \\
\text { fully }\end{array}$ \\
\hline 3 & $\begin{array}{l}\text { I have four children. Three daughters and } \\
\text { one son. Husband got severe health issues. I } \\
\text { learned to tailor. Now I have two tailoring } \\
\text { machines and two helpers are working with } \\
\text { me in my shop. I am getting my husband } \\
\text { treatment along with my kid's schooling. } \\
\text { Daughters also help me in my work. I have } \\
\text { taken a loan of } 45000 \text { while buying tailoring } \\
\text { machines and for the shop and used for my } \\
\text { husband's treatment. }\end{array}$ & $\begin{array}{l}\text { Income } \\
\text { generated for } \\
\text { health and } \\
\text { living }\end{array}$ & $\begin{array}{l}\text { Improve health } \\
\text { conditions and } \\
\text { basic needs }\end{array}$ & $\begin{array}{l}\text { Funds diverted } \\
\text { partially }\end{array}$ \\
\hline 4 & $\begin{array}{l}\text { I have three children. Husband is daily labor } \\
\text { and he is very much addicted to alcohol. He } \\
\text { is not able to meet the basic needs of my } \\
\text { family. I am working to meet all my } \\
\text { expense. I have an idly shop where I sell } \\
\text { idly batter and I prepare foodstuffs and sell. }\end{array}$ & $\begin{array}{l}\text { Income } \\
\text { generated to } \\
\text { meet the basic } \\
\text { needs. }\end{array}$ & $\begin{array}{l}\text { Fulfill basic } \\
\text { needs }\end{array}$ & $\begin{array}{l}\text { Funds utilized } \\
\text { fully }\end{array}$ \\
\hline 5 & $\begin{array}{l}\text { I have three children. due to a poor living } \\
\text { standard, I got dengue fever. I have a } \\
\text { vegetable shop now my husband and my } \\
\text { daughter takes care of that. I have taken a } \\
\text { loan of } 15000 \text { and invested in the shop. It } \\
\text { generates income for our living and two } \\
\text { kids' education. }\end{array}$ & $\begin{array}{l}\text { Income } \\
\text { generated to } \\
\text { meet the basic } \\
\text { needs. }\end{array}$ & $\begin{array}{l}\text { Fulfill basic } \\
\text { needs }\end{array}$ & $\begin{array}{l}\text { Funds diverted } \\
\text { partially }\end{array}$ \\
\hline 6 & $\begin{array}{l}\text { I have on daughter and one son.my son has } \\
\text { a milk dairy. We have } 2 \text { cows and } 3 \text { goats. I } \\
\text { had taken a loan of } 30000 \text { to buy three more } \\
\text { cows. Now able to get more returns. Now } \\
\text { we are planning to buy more cows. }\end{array}$ & $\begin{array}{l}\text { To Improve } \\
\text { the standard } \\
\text { of living }\end{array}$ & $\begin{array}{l}\text { Reinvested } \\
\text { into business }\end{array}$ & $\begin{array}{l}\text { Funds utilized } \\
\text { fully }\end{array}$ \\
\hline 7 & $\begin{array}{l}\text { I have four children. My husband had many } \\
\text { debts due to his alcohol addiction. Not able } \\
\text { to repay.so I started doing the business of } \\
\text { tailoring. At home only.I stitch clothes and } \\
\text { now repaying both. }\end{array}$ & $\begin{array}{l}\text { Repay debts } \\
\text { and income } \\
\text { generation. }\end{array}$ & $\begin{array}{l}\text { Improve the } \\
\text { standard of } \\
\text { living }\end{array}$ & $\begin{array}{l}\text { Funds diverted } \\
\text { partially }\end{array}$ \\
\hline 8 & $\begin{array}{l}\text { I have two kids. I have a stationery shop. I } \\
\text { had taken a } 15000 \text { loan for investing in my } \\
\text { business during Diwali season. } \\
\text { Unfortunately, my son met an accident. I } \\
\text { happened to spent the entire amount for his } \\
\text { treatment. Now finding it difficult to repay } \\
\text { the loan. If some more loan is provided I } \\
\text { can invest in my business repay it without } \\
\text { any difficulty. To repay this loan I am } \\
\text { borrowing from others. }\end{array}$ & $\begin{array}{l}\text { Repay debts } \\
\text { and income } \\
\text { generation }\end{array}$ & $\begin{array}{l}\text { Fulfill basic } \\
\text { needs }\end{array}$ & $\begin{array}{l}\text { Funds diverted } \\
\text { partially }\end{array}$ \\
\hline
\end{tabular}




\begin{tabular}{|c|c|c|c|c|}
\hline Respondents & Example from the raw data & $\begin{array}{l}\text { Theme 1- } \\
\text { impact }\end{array}$ & $\begin{array}{ll}\text { Theme } & 2- \\
\text { utilization } & \text { of } \\
\text { funds } & \\
\end{array}$ & $\begin{array}{l}\text { Theme }-3 \\
\text { funds utilized } \\
\text { /diverted }\end{array}$ \\
\hline 9 & $\begin{array}{l}\text { I have three kids. I had taken a loan from the } \\
\text { private lender to invest in my business at a } \\
\text { higher rate of interest due to no collateral. } \\
\text { Now I have repaid the old loans and } \\
\text { invested in my business. I am able to } \\
\text { support my family. }\end{array}$ & Repay debt & $\begin{array}{l}\text { Fulfill basic } \\
\text { needs }\end{array}$ & $\begin{array}{l}\text { Funds utilized } \\
\text { fully }\end{array}$ \\
\hline 10 & $\begin{array}{l}\text { I have joined in a group taken a loan and } \\
\text { invested in clothes business. Low sells } \\
\text { turnover. Stocks remain ideal in my store. } \\
\text { Not able to repay. Didn't study the local } \\
\text { market as I am not educated. I want my } \\
\text { children to get an education. }\end{array}$ & $\begin{array}{lr}\text { To } & \text { give } \\
\text { children } & \text { a } \\
\text { good } & \\
\text { education } & \end{array}$ & $\begin{array}{lr}\text { improve } & \text { basic } \\
\text { needs } & \text { and } \\
\text { education } & \end{array}$ & $\begin{array}{l}\text { Not utilized } \\
\text { appropriately }\end{array}$ \\
\hline 11 & $\begin{array}{l}\text { I have a hotel business. After my in laws } \\
\text { death, my husband is taking care of it. He } \\
\text { has taken a large amount of debt to meet my } \\
\text { children education and family need. I have } \\
\text { taken a loan of } 45000 \text { and given him. We } \\
\text { are finding very difficult to repay the entire } \\
\text { debt. }\end{array}$ & $\begin{array}{l}\text { To Repay old } \\
\text { debt }\end{array}$ & $\begin{array}{l}\text { Fulfill basic } \\
\text { needs }\end{array}$ & $\begin{array}{l}\text { Not utilized } \\
\text { appropriately }\end{array}$ \\
\hline 12 & $\begin{array}{l}\text { I have a small stationery shop. I have taken } \\
\text { a loan and used for my daughter's delivery. } \\
\text { While sending her I need to buy gold for my } \\
\text { granddaughter then only in-laws will take } \\
\text { her back. I need some more loan to meet my } \\
\text { family need. }\end{array}$ & $\begin{array}{l}\text { To meet the } \\
\text { basic needs }\end{array}$ & $\begin{array}{l}\text { Fulfill basic } \\
\text { needs }\end{array}$ & $\begin{array}{l}\text { Not utilized } \\
\text { appropriately }\end{array}$ \\
\hline 13 & $\begin{array}{l}\text { I have taken a } 15000 \text {. I buy fish in the } \\
\text { wholesale market and sell in the street. I } \\
\text { have put some money in my business and } \\
\text { some money used for my son's health } \\
\text { issues. The return we get use it for meeting } \\
\text { my basic needs after repaying the } \\
\text { installment to a loan officer. }\end{array}$ & $\begin{array}{l}\text { Invested in } \\
\text { business and } \\
\text { health }\end{array}$ & $\begin{array}{l}\text { Fulfill basic } \\
\text { needs }\end{array}$ & $\begin{array}{l}\text { Funds diverted } \\
\text { partially }\end{array}$ \\
\hline 14 & $\begin{array}{l}\text { I have a small stall at my home. I make } \\
\text { foodstuff, papads, pickles, sweets (karaka } \\
\text { pita, Arisa, murukku, mixture etc.). I have } \\
\text { taken a loan and purchased big kitchen } \\
\text { utensils. Now my business is doing very } \\
\text { well. Planning takes a shop and expands my } \\
\text { business.it is giving me good returns. I am } \\
\text { happy that the company helped us. }\end{array}$ & $\begin{array}{l}\text { invested in } \\
\text { asset creation } \\
\text { for business }\end{array}$ & $\begin{array}{l}\text { Used for } \\
\text { further } \\
\text { investment }\end{array}$ & $\begin{array}{l}\text { Funds utilized } \\
\text { fully }\end{array}$ \\
\hline 15 & $\begin{array}{l}\text { My husband has a watch, a TV, radio repair } \\
\text { shop. I have taken a loan for my husband } \\
\text { business. Purchased some stock of watch, } \\
\text { audio, video CDs. But still, sales are very } \\
\text { less. Not able to meet all the expenses of my } \\
\text { family itself. }\end{array}$ & $\begin{array}{l}\text { Invested in } \\
\text { business }\end{array}$ & $\begin{array}{lr}\text { Utilized } & \text { fully } \\
\text { but } & \text { not } \\
\text { effective } & \end{array}$ & $\begin{array}{l}\text { Funds utilized } \\
\text { fully }\end{array}$ \\
\hline 16 & $\begin{array}{l}\text { I have a shop where I sell mud pots, bamboo } \\
\text { baskets, bamboo made items for household } \\
\text { accessories. I have taken a loan in your } \\
\text { company. but finding little difficult to repay } \\
\text { the loan. Sells are very less. Sell are during } \\
\text { festival seasons only to meet the rituals. } \\
\text { Now a day's people are not using these } \\
\text { items much. Still continuing this business } \\
\text { from three generations. }\end{array}$ & $\begin{array}{l}\text { Invested in } \\
\text { business }\end{array}$ & $\begin{array}{lr}\text { Utilized } & \text { fully } \\
\text { but } & \text { not } \\
\text { effective } & \end{array}$ & $\begin{array}{l}\text { Funds utilized } \\
\text { fully }\end{array}$ \\
\hline
\end{tabular}




\begin{tabular}{|c|c|c|c|c|}
\hline Respondents & Example from the raw data & $\begin{array}{l}\text { Theme } \\
\text { impact }\end{array}$ & $\begin{array}{ll}\text { Theme } & 2- \\
\text { utilization } & \text { of } \\
\text { funds } & \\
\end{array}$ & $\begin{array}{l}\text { Theme }-3 \\
\text { funds utilized } \\
\text { /diverted }\end{array}$ \\
\hline 17 & $\begin{array}{l}\text { I have a tailoring shop. I have taken a loan } \\
\text { of } 15000 \text { and purchased tailoring machine. } \\
\text { Helping my family to meet the basic needs. }\end{array}$ & $\begin{array}{l}\text { Invested in } \\
\text { business }\end{array}$ & $\begin{array}{l}\text { Used to meet } \\
\text { basic needs not } \\
\text { reinvested in } \\
\text { the business. }\end{array}$ & $\begin{array}{l}\text { Funds utilized } \\
\text { fully }\end{array}$ \\
\hline 18 & $\begin{array}{l}\text { I have started a clothes business. I purchase } \\
\text { the stocks from Kolkata and sell it here. } \\
\text { Two boys are working for me. doing good } \\
\text { in business. I have purchased a vehicle for } \\
\text { myself. I do collections using that. }\end{array}$ & $\begin{array}{l}\text { Asset creation } \\
\text { for business }\end{array}$ & $\begin{array}{l}\text { Used for } \\
\text { further } \\
\text { investment }\end{array}$ & $\begin{array}{l}\text { Funds utilized } \\
\text { fully }\end{array}$ \\
\hline 19 & $\begin{array}{l}\text { I have a tiffin center where four workers are } \\
\text { working .me and the husband takes care of } \\
\text { it. I have taken a loan and invested in the } \\
\text { business. I am using it to meet my basic } \\
\text { need. Even though my business makes } \\
\text { enough profit I don't know why I am unable } \\
\text { to save. day by day our expenses are } \\
\text { increasing. Unable to have any limit in my } \\
\text { expenses. }\end{array}$ & $\begin{array}{l}\text { Invested in } \\
\text { business }\end{array}$ & $\begin{array}{l}\text { Used to meet } \\
\text { basic needs not } \\
\text { reinvested in } \\
\text { the business }\end{array}$ & $\begin{array}{l}\text { Funds utilized } \\
\text { fully }\end{array}$ \\
\hline 20 & $\begin{array}{l}\text { I have a petty shop and a tea stall in front of } \\
\text { it. I have taken a loan to purchase stock for } \\
\text { my business. The tea stall is running well. } \\
\text { Husband has borrowed money and lost in } \\
\text { fish farming business. Paying that dues from } \\
\text { the returns of my business. }\end{array}$ & $\begin{array}{l}\text { Invested in } \\
\text { business }\end{array}$ & $\begin{array}{l}\text { Returns were } \\
\text { used to repay } \\
\text { the dues not } \\
\text { reinvested in } \\
\text { the business. }\end{array}$ & $\begin{array}{l}\text { Funds utilized } \\
\text { fully }\end{array}$ \\
\hline
\end{tabular}

\section{Findings}

The researcher has collected qualitative data which deals with words. After conducting an interview interim analysis which is a cyclical process of data collection and instant analysis was reflected which helped to record all the reflected data, thoughts, insights, throughout the collection and analysis process. Finally, the researcher collected data until no new thing emerged from the data.

The thematic analysis presented in table 2 shows the utilization of funds given by microfinance programs helped the clients in generating income for improving their standard of living, education, health and used for asset creation for future and also for meeting other family needs.During the interview process, it was observed that around $60 \%$ of the respondents utilized fully in the business whereas rest were diverted it to meet their basic and contingency requirements.

Most of the respondents reported that they do not separate business money from their family uses. Only four respondents told that they maintain a separate account for the business and analyze the returns of their investments. Few respondents blindly decided to follow others and imitating others rather deciding their own independently. Several respondents expressed that they invest in their business without even calculating the cost and benefit of that avenue after all the deductions such as interest rates, tariffs, and taxes. One of the major findings was that respondents were biased about their financial decisions making. They were influenced by others to invest in a business without even studying local market needs.

It was observed that respondents were planned to purchase stocks for their business when its budget run out also. They borrow from other sources without constraining the other kind of purchases. That leads to overindebtedness. One of the respondents was worried about investing in higher risky businesses since she was not willing to take the risk. The result of the study shows that majority of the consumers are unanimous in their opinion that their business programs are not self-sustainable due to the diversion of funds towards present consumptions, repayment of old debts and low returns from their ventures were not sufficient to meet their basic needs. Only a few respondents were able to reinvest their returns in their businesses. Apparently, it was visible that majority of the respondents were not following a financial discipline. Merriam -Webster defined financial discipline is "how well we are able to confirm our saving to the plans that we set to accomplish our monetary goal."

Money is fungible. According to the behavioral theory people are not rational in all the situation. They are carried away with their emotions and biases. Financial instability may arise due to this reason. There are many pieces of evidence where behavioral biases lead the individual to follow the ill-judged decisions of handling finance. (Tversky \& Kahneman 1974; Baddley et al). 
All the respondents were asked regarding the operational evaluation check. Operational evaluation means the effective implementation of the program in accordance with the initial program objective of MFIs. This evaluation is essential by all of the MFIs to seek whether implementation of microfinance program extended as planned. Specifically, it is a reflective assessment based on the program objective. As per the official records, it is mandatory to check after 21 days of the issue date, an operational evaluation must be performed by the loan officers regarding their investment in the various avenues.Researcher's enquiries were done based on the interviews with the MFI clients to check the appropriate utilization of funds in their businesses to identify the gap.It was observed that none of the loan officers were concern about the verification. Their only focus was on disbursement and collection of the loans.

\section{Conclusion}

There are very few studies that have measured the financial sustainability of MFI clients. while most of the studies done were focused on the financial sustainability of MFIs. In this paper, the researcher had tried to explore the reasons behind their financial instability with the help of thematic analysis method using qualitative data. It was clearly evident that MFIs were not focused on the utilization check rather they were only focusing on disbursement and collections of their loans. Due to this reason, the majority of the respondents were using it as additional finance for their family. However many studies revealed that microfinance is beneficiary for poor and some studies were found microcredit has a negative impact on poverty, whereby the poor household simply become poorer through the additional burden of debt (Hulme \&Mosley 1996 ). The result of this study reveals that the impact of the MFI program can be enhanced more by giving stringent verifications on the operational evaluation of the funds. Though it shows a positive sign that many respondents are benefited from the program in terms of meeting their basic needs and were failed to reinvest the returns into the business for attaining sustainability. In this study, it was observed that individual MFI clients were not disciplined in utilizing finance. They were biased in handling finance. Unfortunately, saving can be hampered by the fact that they are not subject to limited control over their expenditure. Most of the incremental returns were also used for improving their livelihood rather were reinvesting into business for gaining sustainability.

"people in standard finance are rational. people in behavioral finance are normal" (Meir Statman). It's all about human psychology to deal with money. people show various behavioral biases like mental accounting bias, heuristics, loss aversion during their financial decision making. Emotions affect the financial decision making of individuals. The important conclusion of the study brings about the behavioral biases that the respondents were showing on their financial decision-making process. As the research paper is written with qualitative data with in-depth details of findings from the interview sessions with small sample size. For future researches, an empirical investigation can be adapted to investigating various biases shown by MFI clients and suitable training program can contribute to overcome these biases by adopting financial disciplines in utilizing money and which can create a difference in people's life.

The uniqueness of the microfinance system is that it recognizes the inability of the poor to provide tangible collaterals, therefore promotes collateral substitution for the small business entrepreneurs. If the loan amount and the opportunity for entrepreneurial activity appropriately utilized that may lead to permanent income by reinvesting in the business. If the clients follow disciplinary utilization of finance by employing stringent practices in handling day to day finance and put limits on their consumptions, achieving the sustainability goal is not so far.

\section{References}

Acharya, Y.P. and Acharya, U., 2006. Sustainability of Microfinance Institution from Small Farmer's Perspective: a. A case of Rural Nepal. International Review of Business Research Papers, 2(2), pp.117-126.

Ambe Shu, C. and Oney, B., 2014. Outreach and performance analysis of microfinance institutions in Cameroon. Economic research-Ekonomska istraživanja, 27(1), pp.107-119.

Attanasio, O., Augsburg, B., De Haas, R., Fitzsimons, E. and Harmgart, H., 2014. Group lending or individual lending? Evidence from a randomized field experiment in Mongolia (No. SP II 2014-303). WZB Discussion Paper.

Aubert, C., de Janvry, A. and Sadoulet, E., 2009. Designing credit agent incentives to prevent mission drift in pro-poor microfinance institutions. Journal of Development Economics, 90(1), pp.153-162.

Baddeley, A.D., and Hitch, G., 1974. Working memory. In Psychology of learning and motivation (Vol. 8, pp. 47-89). Academic Press.

Barr, M.S., 2004. Microfinance and financial development. Mich. J. Int'l L., 26, p.271.

Bhattacharya, S., Banerjee, S. and Mukherjee, S., 2008. Group lending and self-help groups: joint benefit as an alternative governance mechanism. The Journal of International Trade \& Economic Development, 17(1), pp.1-19.

Braun, V., Clarke, V. and Terry, G., 2014. Thematic analysis. Qual Res Clin Health Psychol, 24, pp.95-114. 
Brugmann, J. and Prahalad, C.K., 2007. Cocreating business's new social compact. Harvard business review, $85(2)$, p.80.

Brünjes, J. and Diez, J.R., 2013. 'Recession push'and 'prosperity pull'entrepreneurship in a rural developing context. Entrepreneurship \& Regional Development, 25(3-4), pp.251-271.

Copestake, J., 2007. Mainstreaming microfinance: Social performance management or mission drift?. World development, 35(10), pp.1721-1738.

Crépon, B., Devoto, F., Duflo, E. and Parienté, W., 2015. Estimating the impact of microcredit on those who take it up: Evidence from a randomized experiment in Morocco. American Economic Journal: Applied Economics, 7(1), pp.123-50.

Dzene, R. and Asiedu, K.F., 2010. Gender Composition, Competition and Sustainability of MicroFinance in Africa: Evidence from Ghana's Microfinance Industry. Ghana Institute of Management and Public Administration.

Goldberg, N., 2005. Measuring the impact of microfinance: taking stock of what we know. Grameen Foundation USA publication series, pp.1-52.

Jose, S. and Chacko, J., 2017. Sustainable development of microfinance customers: An empirical investigation based on India. Journal of Enterprise Information Management, 30(1), pp.49-64.

Karlan, D., Kendall, J., Mann, R., Pande, R., Suri, T. and Zinman, J., 2016. Research and impacts of digital financial services (No. w22633). National Bureau of Economic Research.

Mazumder, M.S.U. and Lu, W., 2015. What impact does microfinance have on rural livelihood? A comparison of governmental and non-governmental microfinance programs in Bangladesh. World Development, 68, pp.336-354.

Mersland, R. and Strøm, R.Ø., 2010. Microfinance mission drift?. World Development, 38(1), pp.28-36.

Mia, M.A., and Lee, H.A., 2017. Mission drift and ethical crisis in microfinance institutions: What matters? Journal of cleaner production, 164, pp.102-114.

Morduch, J., 1999. The microfinance promise. Journal of economic literature, 37(4), pp.1569-1614.

Morduch, J., 2000. The microfinance schism. World development, 28(4), pp.617-629.

Mosley, P. and Hulme, D., 1998. Microenterprise finance: is there a conflict between growth and poverty alleviation?. World development, 26(5), pp.783-790.

Natilson, N. and Bruett, T., 2001. Financial Performance Monitoring: A Guide for Board Members of Microfinance Institutions. Bethesda: Development Alternatives.

Rosenberg, R., Gonzalez, A., and Narain, S., 2009. The new moneylenders: are the poor being exploited by high microcredit interest rates?. In Moving beyond storytelling: Emerging research in microfinance (pp. 145181). Emerald Group Publishing Limited.

Serrano-Cinca, C., Gutiérrez-Nieto, B. and Reyes, N.M., 2016. A social and environmental approach to microfinance credit scoring. Journal of cleaner production, 112, pp.3504-3513.

Shirsendu Mukherjee,sukanta Bhattacharya .,2015.Optimal group size with joint liability group lending strategy.Indian growth and development review, vol.8 Iss 1pp.2-18

Thapa, G., 2007. Sustainability and governance of microfinance institutions: Recent experience and lessons from South Asia. International Fund for Agriculture Development, Rome, Asian Journal of Agriculture and Development, 3(1\&2).

Tversky, A. and Kahneman, D., 1974. Judgment under uncertainty: Heuristics and biases. science, 185(4157), pp.1124-1131.

Xu, S., Copestake, J. and Peng, X., 2016. Microfinance institutions' mission drifts in a macroeconomic context. Journal of International Development, 28(7), pp.1123-1137. 